\title{
CAN PORTABLE ANALYZERS BE RELIABLE FOR BIOGAS CHARACTERIZATION?
}

Nathalia Silva Oliveira ${ }^{1}$ (D), André Pereira Rosa ${ }^{1}$ (D), Izabelle de Paula Sousa*1 (D), Juciara Oliveira Lopes ${ }^{1}$ (D), Alisson Carraro Borges $^{1}$ (1D) \& Ronaldo Perez ${ }^{1}$ (BD)

1 - Federal University of Viçosa

\section{Keywords:}

Covered lagoon biodigesters

Biogas

Anaerobic digestion

Methane

Pig farming

\section{ABSTRACT}

Anaerobic digestion for treatment of swine wastewater is an attractive alternative, among other aspects, for the generation of biogas. This gas is composed predominantly of methane and can be converted into electrical and thermal energy. However, the knowledge of the biogas composition is of paramount importance, especially regarding the methane content due to its energetic properties. The alternatives for this determination usually require high cost and specialized technicians. Therefore, the search for simple and low cost alternative solutions and techniques can improve the biogas use as an energy source and favor energy sustainability in pig farming. The present study aimed to compare the results of the methane composition of a portable analyzer with that of a Gasboard gas analyzer. The biogas was collected and characterized in a full cycle swine farm from January to December 2019 in the municipality of Teixeiras (MG), Brazil. The methane composition values did not differ statistically for a $5 \%$ significance level between the evaluated methods. The use of the portable kit is a simple and low cost alternative in determining the methane content in biogas and can be used reliably.

\section{Palavras-chave: \\ ANALISADORES PORTÁTEIS PODEM SER CONFIÁVEIS PARA \\ Biodigestores lagoa coberta CARACTERIZAÇÃO DO BIOGÁS? \\ RESUMO}

Digestão anaeróbia

Metano

Suinocultura
A digestão anaeróbia para o tratamento de efluentes de suinoculturas é uma alternativa atraente, dentre outros aspectos pela geração do biogás. Composto predominantemente por metano, esse gás pode ser convertido em energia elétrica e térmica. Entretanto o conhecimento da composição do biogás é de suma importância, em especial o teor de metano em virtude de suas propriedades energéticas. As alternativas para esta determinação normalmente requerem alto custo e técnicos especializados e portanto, a busca de soluções e técnicas alternativas simples e de baixo custo pode aprimorar o aproveitamento do biogás como fonte de energia e favorecer a sustentabilidade energética na suinocultura. No presente trabalho teve-se por objetivo comparar os resultados da composição de metano de um analisador portátil com de um analisador de gases Gasboard. O biogás foi coletado e caracterizado em uma suinocultura de ciclo completo no período de janeiro a dezembro de 2019 no município de Teixeiras (MG). Os valores da composição de metano não diferiram estatisticamente para um nível de significância de $5 \%$ entre os métodos avaliados. Conclui-se que a utilização do kit portátil é uma alternativa simples e de baixo custo na determinação da composição do metano no biogás e pode ser utilizado de forma confiável.
36

SECTION EDITOR IN CHARGE

Erlon Lopes Pereira
Recebido para publicação em 17/09/2020 • Aprovado em 29/12/2020 • Publicado em 25/04/2021

Email (corresponding author)*: izabelle.sousa@ufv.br 


\section{INTRODUCTION}

Technological advances in pig production have enabled large-scale production, causing the intensive pig rearing in a confined regime. However, this type of management produces a high amount of manure that requires treatment before final disposal (LEITÃO; SILVA, 2018). Among the existing treatment systems for pig manure, the use of anaerobic biodigesters stands out. This system reduces the organic load of the effluent in addition to generating by-products with added value, such as biogas and biofertilizer (SILVA et al., 2020).

As a result of the anaerobic degradation process, there is the production of a gaseous by-product. The biogas is composed of several gases, with a predominance of methane $\left(\mathrm{CH}_{4}\right)$ and carbon dioxide $\left(\mathrm{CO}_{2}\right)$, beyond elements in lower concentration such as hydrogen sulphide $\left(\mathrm{H}_{2} \mathrm{~S}\right)$, nitrogen $\left(\mathrm{N}_{2}\right)$ and water vapor (BRASIL, 2015). Methane is considered the most relevant gas in terms of the greenhouse effect, presenting a global warming potential 21 times higher than carbon dioxide. On the other hand, its high calorific value allows it to be used to generate thermal, electric and fuel for vehicles, presenting an energy potential similar to that of natural gas (PINÃS et al., 2016).

The knowledge of the methane content in biogas is of great relevance; among the main reasons, it can be highlighted: (i) it favors the understanding of the dynamics of the routes of conversion of organic matter in the treatment system; (ii) it allows assessing the technical viability of systems for converting biogas to electricity; and (iii) it is an important response variable for the system.

The characterization of the methane content can be done more accurately through gas chromatography or by gas analyzers. However, the costs are high and these alternatives are generally not accessible to producers. In addition, the sector still demands specialized companies that provide such services, which is often impracticable, since many farms are far from laboratories and specialized companies. The use of low-cost equipment that provides, even without great precision, the $\mathrm{CH}_{4}$ concentration is of interest for monitoring treatment systems and understanding of alternatives for energy sustainability in pig farms. The present study aimed to evaluate the adherence of the methane contents measured by a portable equipment that operates by the volumetric principle and a gas analyzer.

\section{MATERIAL AND METHODS}

Monitoring was performed in a pig farming located in the municipality of Teixeiras, Minas Gerais, Brazil. Biogas collections and characterization were performed from January to December 2019. The property has full cycle pig activity, subdivided into the nursery, breeding, maternity, pregnancy and sale sectors with a capacity of 1,631 breeding stock, with the waste treated by two parallel "covered lagoon" biodigesters followed by three facultative ponds in series.

Biogas collections were performed in 5-liter bags at the outlet of the biodigesters. The methane content was quantified by two different analytical methods, the first one was the volumetric method through a portable biogas analyzer developed by Embrapa Swine and Poultry in partnership with company Alfakit LTDA (KUNZ; SULZBACH, 2007), and the second one was the infrared electronic method in a Gasboard 3100 gas analyzer, which is used in several studies, in order to quantify the composition of gases originated in anaerobic digestion and carbonization processes (ORTIZ-SANCHEZ et al., 2020; GOMES et al., 2019; SRIWURYANDARI et al., 2017). Figure 1 shows a schematic representation of the biogas production, collection and characterization system.

The portable kit allows the quantification of $\mathrm{CH}_{4}$ and $\mathrm{CO}_{2}$ levels in a simple and fast way. The principle of its operation is based on the selective absorption of gas by chemical reagent based on the adaptation of the Orsat method (Alfakit, 2020). After the biogas collection, $20 \mathrm{~mL}$ of gas is sucked from the collector bag using a syringe and it is connected to the portable kit using a three-way, where the volume is moved to another syringe coupled with $5 \mathrm{~mL}$ of $\mathrm{KOH}$ solution. After stirring, the $\mathrm{CO}_{2}$ is absorbed by the $\mathrm{KOH}$, making it possible to determine its concentration and indirectly, by volumetric difference, the $\mathrm{CH}_{4}$ content.

The Gasboard 3100 gas analyzer quantifies the levels of $\mathrm{CH}_{4} \mathrm{CO}_{2}, \mathrm{CO}, \mathrm{H}_{2}, \mathrm{O}_{2}$ and Hydrocarbons, but for this study we considered only the $\mathrm{CH}_{4}$ 


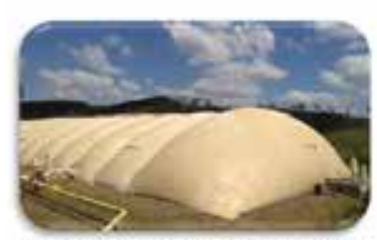

Covered lagoon biodigester

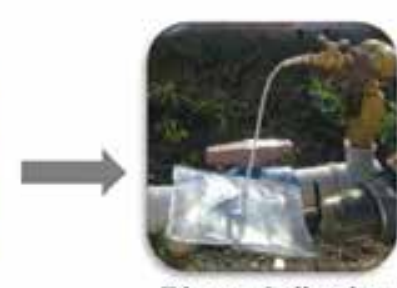

Biogas Collection
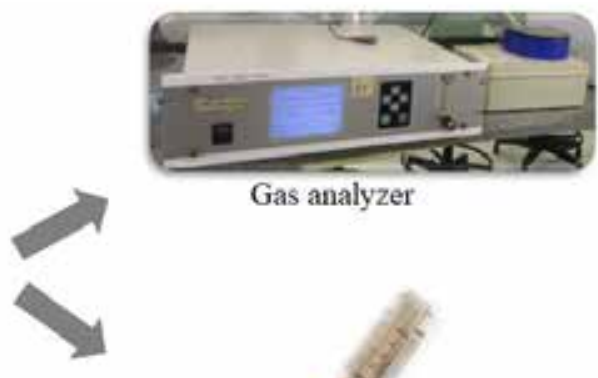

Gas analyzer

Portable kit (Alfakit)

Figure 1. Illustrative scheme indicating the production, collection and characterization of biogas

content. The operation principle of the equipment consists of the suction of the gas present in the collector bag using a small pump, directing the gas flow to a filter with hydrophobic membrane and later to the reading sensors.

The biogas sample collected in the pig farming was quantified by the two equipments for comparison of the analytical methods. The data were submitted to an analysis of variance
(ANOVA) with 5\% significance, using the R3.6.3 software (R Core Team, 2013).

\section{RESULTS AND DISCUSSION}

The methane contents obtained by the two analytical methods are presented in Figure 2 as a box-plot graph. The descriptive statistics of the data is presented in Table 1.

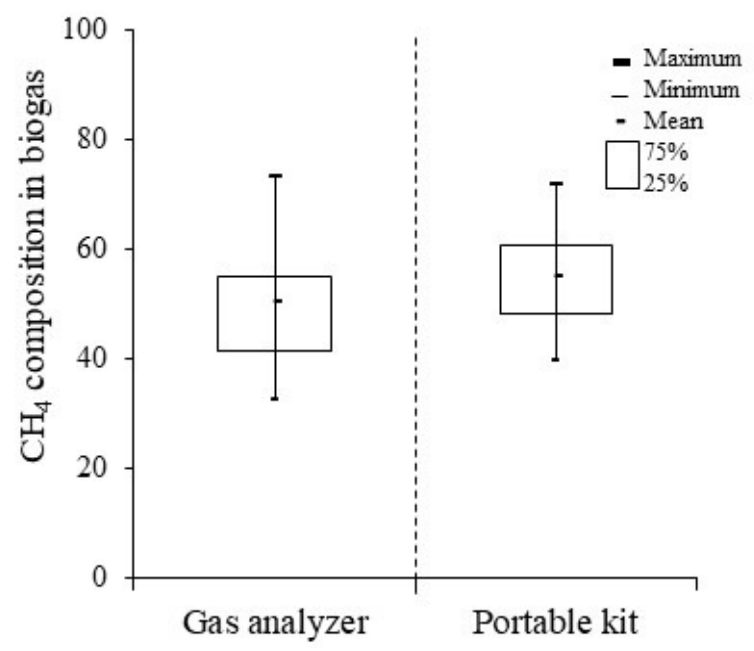

Figure 2. Box-plot graph of $\mathrm{CH}_{4}$ composition in biogas samples from the different analytical methods evaluated

Table 1. Descriptive statistics of data obtained from $\mathrm{CH}_{4}$ content from the two methods evaluated

\begin{tabular}{llll}
\hline Statistics & Gas analyzer & Portable kit & Unit \\
\hline Number of data & 18 & 18 & - \\
Median & 46.8 & 55.2 & $\%$ \\
Mean & 49.0 & 54.7 & $\%$ \\
Minimum & 33.0 & 40.0 & $\%$ \\
Maximum & 73.3 & 71.7 & $\%$ \\
SD & 10.1 & 7.9 & $\%$ \\
CV & 20.7 & 14.4 & $\%$ \\
\hline
\end{tabular}

SD - standard deviation. CV- coefficient of variation 
The percentage of $\mathrm{CH}_{4}$ in swine biogas (Figure 2 and Table 1) quantified by the portable kit ranged from 40.0 to $71.7 \%$, with a mean value of $54.7 \%$. For the gas analyzer, the $\mathrm{CH}_{4}$ percentage ranged from 33.0 to $73.3 \%$, with a mean value of $49.0 \%$.

No statistical difference was observed between the mean values of the $\mathrm{CH}_{4}$ results obtained for the two methods, at $5 \%$ significance level, which points to the adherence of the data from the portable kit to the more robust and precise analytical method.

\section{CONCLUSION}

- The methane levels obtained by the portable kit and by the gas analyzer did not differ statistically at $5 \%$ significance level.

- Both methods, biogas analysis kit and analyzer, can be used to determine the percentage of methane for qualitative purposes and to analyze the variation of its the composition.

- The kit method has as advantages the simplicity of analysis and characterization of biogas, the possibility of carrying out on-site analysis and the greater number of repetitions.

\section{AUTHORSHIP CONTRIBUTION STATEMENT}

OLIVEIRA, N.S.: acquisition of data, analysis and interpretation of data, drafting the work; ROSA, A.P: supervision and conception of the research, analysis and interpretation of data, drafting and revising the work; SOUZA, I.P: acquisition of data, analysis and interpretation of data, drafting and revising the work; LOPES, J.O: acquisition of data, analysis and interpretation of data, revising the work; BORGES, A.C.: interpretation of data, revising the work; PEREZ, R.: revising the work.

\section{DECLARATION OF INTERESTS}

The authors declare that they have no known competing financial interests or personal relationships that could have appeared to influence the work reported in this paper.

\section{ACKNOWLEDGMENTS}

This study was partially funded by the Coordination for the Improvement of Higher
Education Personnel - Brazil (CAPES) - Finance Code 001, National Council for Scientific and Technological Development - Brazil (CNPq) Grant \# 140417/2020-6 and Minas Gerais State Research Foundation (FAPEMIG), Grant \# APQ01109-18.

\section{REFERENCES}

ALFAKIT. Disponível em https://alfakit.com.br/ produtos/kit-analise-de-biogas-cod-3819/ Acesso em 28/12/2020.

BRASIL. Secretaria Nacional de Saneamento Ambiental. Probiogás. Tecnologias de digestão anaeróbia com relevância para o Brasil: substratos, digestores e uso de biogás. Brasília, DF: Ministério das Cidades, 2015.

KUNZ, A.; SULZBACH, A. Kit biogás portátil. Concórdia: EMBRAPA - CNPSA, 2007.

GOMES, A. F.; MARTINS, M. A.; PEREIRA, E. G. Simulação computacional de dispositivos de mistura em câmara de combustão para gases de carbonização. Ciência Florestal, v.29, n.2, p.673684, 2019.

LEITÃO, F. O.; SILVA, W. H. Geração de energia e renda a partir do tratamento dos resíduos da suinocultura. IGepec, v. 22, n.1, p.116-132, 2018.

ORTIZ-SANCHEZ, M.; SOLARTE-TORO, J.; GONZÁLES-AGUIRRE, J.; PELTONEN, K. E.; RICHARD, P.; ALZATE, C. A. C. Pre-feasibility analysis of the production of mucic acid from orange peel waste under the biorefinery concept. Biochemical Engineering Journal, v.161, p.107680, 2020.

PINÃS, J. A. V.; VENTURINI, O. J.; LORA, E. E. S.; OLIVEIRA, M. A.; ROALCABA, O. D. C. Aterros sanitários para geração de energia elétrica a partir da produção de biogás no Brasil: comparação dos modelos LandGem (EPA) e biogás (CETESB). Revista Brasileira de Estudos de População. Rio de Janeiro, v.33, n.1, p.175-188, 2016. 
OLIVEIRA, N. S. et al.

R Core Team. R: A language and environment for statistical computing. 2013.

SILVA, J. A. R.; TERRA, A. B. C.; ASSIS, C.; FLORENTINO, L. A.; PUTTI, F. F.; Tratamento de dejetos no Brasil: Comparativo entre as técnicas de compostagem e biodigestores anaeróbios. Revista em Agronegócio e Meio Ambiente. Maringá, v.13, n.2, p.797-817, 2020.

SRIWURYANDARI, L.; EKAPUTRA, P. A.; SINTAWARDANI, N. Gas production in anaerobic dark-fermentation processes from agriculture solid waste. E\&ES, v.60, n.1, p. 012030, 2017. 